\title{
Can We Use the Silodosin as Second Line Treatment of Benign Prostate Hyperplasia?
}

\section{Benign Prostat Hiperplazisi Tedavisinde Silodosin İkinci Basamak Kullanılabilinir mi?}

\section{Bekir Voyvoda $^{1}$ (D), Omur Memik ${ }^{1}$ (D), Onur Karsli ${ }^{1}$ (D), Murat Ustuner ${ }^{1}$ (D), Levent Ozcan ${ }^{2}$ (D)}

${ }^{1}$ Department of Urology, University of Health Sciences, Derince Training and Research Hospital, Kocaeli, Turkey

${ }^{2}$ Department of Urology, University of Health Sciences, Prof. Dr. Cemil Tascioglu City Hospital, Istanbul, Turkey

Cite as: Voyvoda B, Memik O, Karsli O, Ustuner M, Ozcan L.

Can we use the silodosin as second line treatment of benign prostate hyperplasia? Grand J Urol 2021;1(3):122-7.

Submission date: 07 August 2021

Acceptance date: 13 September 2021

Online First: 17 September 2021

Publication date: 20 September 2021

Corresponding Author: Bekir Voyvoda / University of Health Sciences, Derince Training and Research Hospital, Department of Urology, Kocaeli, Turkey / voyvodab@yahoo.com ORCID ID: 0000-0002-0696-7381

\begin{abstract}
Objective: We aimed to investigate the efficacy of silodosin in patients with lower urinary tract symptoms (LUTS) caused by benign prostatic hyperplasia (BPH) refractory to previous $\alpha$-adrenergic receptor (AR) blocker therapy.

Materials and Methods: Patients who did not benefit from alpha-blocker therapy but avoided surgical treatment constitute the population of our study. Seventy-five patients were studied in each group; Group 1 was given $8 \mathrm{mg}$ of silodosin, while Group 2 continued the previous alpha-blocker treatment. Results: The initial mean international prostate symptom score (IPSS) was calculated as $20.81 \pm 0.97$ in Group 1, in the third month there was a decrease of $17.12 \pm 1.25(\mathrm{p}<0.05)$. No significant change was observed in Group 2. In addition, a significant decrease was observed in IPSS subscores (storage and voiding symptoms) in Group 1 compared to baseline at the third month. There was an improvement in residual urine in the silodosin group and no improvement in the other group.

Conclusion: In patients with BPH who refuse surgical treatment and could not achieve adequate symptom relief with other $\alpha$-blockers in routine practice, silodosin was found superior in terms of LUTS recovery. Silodosin is also an effective option in patients who cannot undergo surgical treatment due to comorbidities.
\end{abstract}

Keywords: silodosin, alpha blocker, benign prostate hyperplasia, BPH treatment

Öz

Amaç: Daha önce alfa bloker tedavi ile iyileşme sağlanamayan benign prostat hiperplazisi (BPH) ile ilişkili alt üriner sistem semptomlu (AÜSS) hastalarda silodosin etkinliğinin ortaya konulması amaçlandı.

Gereç ve Yöntemler: Alfa bloker tedavisinden fayda görmeyen ancak cerrahi tedavi istemeyen hastalar bu çalışmaya dahil edildi. Kayıt sırasında, sırasıyla Grup 1 ve Grup 2'ye 75'er hasta kaydedildi. Grup 1 tedavide silodosin $8 \mathrm{mg}$ alan, Grup 2 diğer $\alpha$ blokerleri alan grup olarak belirlendi.

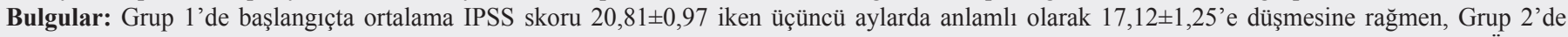
anlamlı bir değişiklik gözlenmedi. Grup 1'de ise her iki IPSS alt puanı için de düşüş gözlendi, üçüncü ayda başlangıca göre anlamlı olarak azaldı. Üçüncü ayın sonunda silodosine geçildikten sonra bu parametrede ilk değere göre $(p<0,05)$ anlamlı bir iyileşme gözlendi. Rezidü idrar ile ilgili olarak silodosin grubunda iyileşme belirgin iken Grup 2'de anlamlı bir iyileşme gözlenmedi.

Sonuç: Bu çalıșmada, cerrahi tedavi öncesi rutin klinik uygulamada diğer $\alpha$-blokerlerle tatmin edici semptom kontrolü sağlanamayan BPH'li hastalarda silodosinin AÜSS iyileşmesi üzerinde etkisi daha fazla bulundu. Silodosin, cerrahi morbiditesi olan BPH'li hastalarda daha etkilidir. Böylece en azından farklı komorbiditeleri olan hastalar cerrahinin morbiditelerinden korunmuş olacaktır.

Anahtar kelimeler: silodsin, alfa bloker, benign prostat hiperplazisi, BPH tedavisi

ORCID ID: O. Melik 0000-0003-0328-8444

O. Karsli $0000-0003-4473-6602$
M. Ustuner

L. Ozcan
0000-0002-3708-8486

0000-0001-9610-9876

(C) Copyright 2021 by GJU. This journal is published by Logos Medical Publishing. This is an Open Access article distributed under the terms of the Creative Commons Attribution NonCommercial License (http://creativecommons.org/licenses/by-nc/4.0) which permits unrestricted non-commercial re-use, distribution, and reproduction in any medium, provided the original work is properly cited. 


\section{Introduction}

Benign prostatic hyperplasia (BPH) is a widespread disease among elderly men. It was also known that in men beyond the age of 50 histological BPH will develop [1]. As a result of the proliferation of epithelial and stromal cells, prostate gland growth occurs and it is characterized with an increase in the micturition frequency, difficulties in initiating micturition, nocturia, urgency, a low stream of urine, and a prolonged period of micturition [2]. All these disorders should be called as lower urinary tract symptoms (LUTS). Stimulation of $\alpha$-adrenergic receptors (ARs), resistance increases in hyperplastic prostate tissue, capsule, prostatic urethra and, bladder outlet. This is an important pathological mechanism in BPH-associated LUTS [3]. $\alpha 1 \mathrm{~A}-\mathrm{ARs}$ and $\alpha 1 \mathrm{D}-\mathrm{ARs}$ mRNA are present in hyperplastic stromal prostate as well as in normal human prostate. Expression of $\alpha 1 \mathrm{~A}-\mathrm{AR}$ is particularly increased in BPH [4-7]. The stromal $\alpha 1 \mathrm{~A}-\mathrm{ARs}$ play an important role in the contraction of the prostate and, consequently, in the dynamism of BPH. Their antagonism may explain the relief of micturition difficulty [8]. In the prostatic contraction, the predominance of the $\alpha$-1ARs subtype may play a primary role, so that this has led to investigation the $\alpha$-1ARs-selective compounds in the notion of uroselectivity or prostate selectivity [9].

Studies have reported that silodosin has a higher affinity for the $\alpha 1 \mathrm{~A}$-ARs than the $\alpha 1 \mathrm{~B}-\mathrm{ARs}$ subtype and also higher selectivity for the lower urinary tract. Silodosin has $>162$-fold greater selectivity for the $\alpha 1 \mathrm{~A}$ over the $\alpha 1 \mathrm{~B}$ subtype and $>50$ fold greater selectivity for the $\alpha 1 \mathrm{~A}$ over the $\alpha 1 \mathrm{D}$ subtype [10]. Thus, of all commercially available $\alpha 1$-AR blockers, silodosin is the most uro-selective and most potent relaxant in vitro to the prostate mediated by $\alpha 1$-ARs [5,11-14]. Oral silodosin is a highly selective $\alpha$-1A-ARs antagonist which rapidly improves LUTS caused by BPH and allows the improvements in storage and voiding symptoms [15].

In our study, we evaluated the efficacy of silodosin in patients with LUTS caused by BPH refractory to previous AR blocker therapy.

\section{Matherials and Methods}

Prior to this study, approval was obtained from the Derince Training and Research Hospital Ethics Committee (Approval no: 2020/62). In our study, patients who switched to silodosin treatment were retrospectively examined. Patients whose alpha-blocker treatments other than silodosin were ineffective and who did not prefer surgical treatment were included in this study. Other inclusions criteria were as follows: international prostate symptoms score (IPSS) $\geq 8$ points, quality of life (QoL) scale $\geq 3$ points, prostate volume by ultrasonography $<40 \mathrm{~mL}$; maximal urinary flow rate (Qmax) $<15 \mathrm{~mL} / \mathrm{s}$ and post-voiding residual (PVR) $\leq 150 \mathrm{ml}$; prostate specific antigen (PSA) $<4 \mathrm{ng} /$ $\mathrm{ml}$. Exclusion criteria were as follows: patients with a diagnosis of neurogenic bladder, with concomitant prostate or urethral carcinoma, with urinary tract infections, using drugs such as anticholinergic agents, beta- 3 adrenoceptor agonists and 5- $\alpha$ reductase inhibitors, and those with a history of prostate surgery.

\section{Study Setting and Design}

This was a retrospective, single-center study conducted at urology clinic of Derince Training and Research Hospital.

\section{Study Procedures}

The patients were informed that silodosin is a new $\alpha$-blocker that was recently released that could be more effective for their symptoms and could have a different side effect profile. When the patient agreed to undergo this change, we switched the drug after 2 weeks of washout period. Oral administration of silodosin at a daily dose of $8 \mathrm{mg}$ started.

A total of 150 patients were divided into two equal groups of 75 patients each. Group 1 received silodosin $8 \mathrm{mg}$ and Group 2 received their previous $\alpha$ blocker. The symptom scores and uroflowmetry with PVR evaluation were measured in both groups after 3 months.

\section{Study Endpoints}

The primary end-point of evaluation for efficacy was the change in total IPSS from baseline and the quality of life (QoL) scale; secondary end-points were changes in Qmax, residual urinary volume and evaluation of subjective symptoms as IPSS voiding and storage subscores and QoL scale. A 20\% decrease in baseline IPSS and a 20\% increase in baseline Qmax were considered as improvement [16].

\section{Statistical Analysis}

Statistical Package for the Social Sciences (SPSS) 15.0 for Windows program was used. For intergroup comparisons Student's t-test, and Mann-Whitney U test were employed. For the comparison of intragroup pre and post-treatment values, analysis of repeated measurements, and Wilcoxon Signed Rank Test were used. Level of statistical significance was accepted as $\mathrm{p}$ values lower than 0.05 .

\section{Results \\ Patient Population}

There was no difference between the two groups in terms of age, prostate volume, IPSS and Qmax (Table 1). The mean duration of previous drug use was calculated as $22.66 \pm 25.84$ months. All of the patients in group 1 used silodosin $(n=75)$ and in the Group 2 tamsulosin $(n=25)$, alfuzosin $(n=20)$ and doxazosin $(n=30)$ were used . During the 3 -month treatment period, no patients discontinued silodosin due to adverse effects. 
Table 1. Comparison of baseline values of both groups (Mann-Whitney U test were used)

\begin{tabular}{l|l|l|l}
\hline & $\begin{array}{l}\text { Group 1 } \\
(\text { mean } \pm \text { SD) }\end{array}$ & $\begin{array}{l}\text { Group 2 } \\
(\text { mean } \pm \text { SD) }\end{array}$ & P-value \\
\hline Numbers & 75 & 75 & \\
\hline Age (year) & $67,1 \pm 2,06$ & $64 \pm 2,11$ & 0,989 \\
\hline PV $(\mathrm{mL})$ & $38,81 \pm 1,94$ & $38,45 \pm 1,94$ & 0,491 \\
\hline IPSS (total score) & $20,81 \pm 0,97$ & $20,77 \pm 0,78$ & 0,871 \\
\hline IPSS - storage symptoms & $11,09 \pm 1,18$ & $11,21 \pm 1,19$ & 0,818 \\
\hline IPSS - voiding symptoms & $8,55 \pm 0,60$ & $10,88 \pm 0,73$ & 0,000 \\
\hline Qmax (mL/sec) & $8,56 \pm 1,58$ & $8,56 \pm 1,58$ & 1,000 \\
\hline PVR (mL) & $53,67 \pm 5,41$ & $53,60 \pm 5,30$ & 0,961 \\
\hline QoL & $5,19 \pm 0,59$ & $5,19 \pm 0,59$ & 1,000 \\
\hline
\end{tabular}

PV: prostate volume; IPSS: international prostate symptom score; Qmax: maximum urine flow rate; PVR: post-void residue; QoL: quality of life

Table 2. Comparison of changes in values in both groups (Wilcoxon Signed Rank test were used)

\begin{tabular}{l|l|l|l|l|l}
\hline & & $\begin{array}{l}\text { Pretreatment } \\
(\mathbf{m e a n} \pm \mathbf{S D})\end{array}$ & $\begin{array}{l}\text { Posttreatment } \\
(\mathbf{m e a n} \pm \mathbf{S D})\end{array}$ & $\begin{array}{l}\text { Change between pre and } \\
\text { posttreatment values (\%) }\end{array}$ & P-value \\
\hline \multirow{5}{*}{ Group 1 } & IPSS-total & $20,81 \pm 0,97$ & $17,12 \pm 1,25$ & 17,6 & 0,000 \\
\cline { 2 - 6 } & IPSS - storage symptoms & $11,09 \pm 1,18$ & $8,56 \pm 0,64$ & 22,3 & 0,000 \\
\cline { 2 - 6 } & IPSS - voiding symptoms & $8,55 \pm 0,60$ & $6,99 \pm 0,34$ & 18 & 0,000 \\
\cline { 2 - 6 } & Qmax (mL/sec) & $8,56 \pm 1,58$ & $11,69 \pm 1,20$ & 39,9 & 0,000 \\
\cline { 2 - 6 } & PVR $(\mathrm{mL})$ & $53,67 \pm 5,41$ & $35,87 \pm 4,96$ & 32,5 & 0,000 \\
\cline { 2 - 6 } & QoL & $5,19 \pm 0,59$ & $3,09 \pm 0,47$ & 40,2 & 0,000 \\
\hline \multirow{5}{*}{ Group 2 } & IPSS-total & $20,77 \pm 0,78$ & $20,96 \pm 0,48$ & 1,0 & 0,070 \\
\cline { 2 - 6 } & Qmax (mL/sec) & $8,56 \pm 1,58$ & $8,48 \pm 0,67$ & 2,8 & 0,602 \\
\cline { 2 - 6 } & PVR (mL) & $53,60 \pm 5,30$ & $57,41 \pm 3,65$ & 7,7 & 0,000 \\
\cline { 2 - 6 } & QoL & $5,19 \pm 0,59$ & $5,27 \pm 0,62$ & $2,0(\%)$ & 0,221 \\
\hline
\end{tabular}

IPSS: international prostate symptom score; Qmax: maximum urine flow rate; PVR: post-void residue; QoL: quality of life

\section{International Prostate Symptom Score (IPSS)}

While the initial mean IPSS score was calculated as $20.81 \pm 0.97$ in Group 1, this value decreased to $17.12 \pm 1.25$ in the third month with a significant difference $(p<0.05)$. No significant change was observed in Group 2. In addition, a significant decrease was observed in IPSS subscores (storage and voiding symptoms) in Group 1 compared to baseline at the third month. Data on IPSS scores are shown in Table 2.

\section{Quality of Life Scale (QOLS)}

At the end of the third month, a significant improvement in QoL scale was monitored after changing to silodosin, as compared with the first value $(\mathrm{p}<0,05)$.

\section{Post-void Residue (PVR)}

When PVR was compared compared, significant improvement was observed in Group 1 but none in Group 2.
After 3 months evaluation, surgical intervention for BPH were applied in $10(13,3 \%)$ patients of the Group 2. The flow chart of study is schematically illustrated in Figure 1.

\section{Discussion}

To the best of our knowledge, there is many studies for the treatment modalities of BPH with alfa blockers. The guidelines issued by the European Association of Urology (EAU) and American Urological Association (AUA) both states that alpha-blockers should be considered as the first-line medical therapy for men with bothersome, moderate to severe LUTS, and their clinical efficacy are similar in recommended therapeutic dose but for some of these drugs, studies reported that side effect profiles are more favorable $[17,18]$. Efficacy of all $\alpha$-AR blockers in appropriate doses seems to be similar in clinical practice treatment efficacy but differs among individuals. Therefore, frequently applied application in clinical practice is switching intra-class $\alpha$-AR blocker to another [19-21]. One of the surgical indication of BPH is a negative response to conservative pharmacological treatment [22]. 


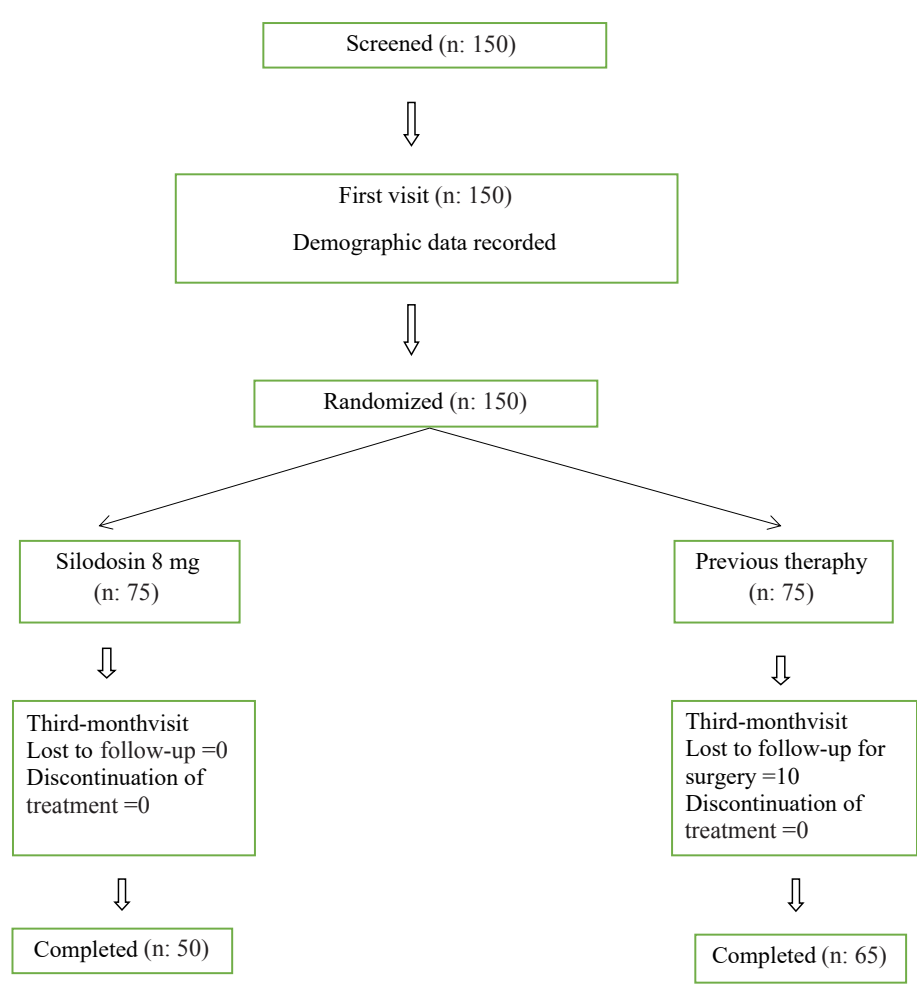

Figure 1. Flow of study participants through the study

In this retrospective study we evaluated the clinical outcomes associated with switching to silodosin in patients who did not respond to other $\alpha$-AR blockers therapy. According to our study it has demonstrated that in patients refractory to $\alpha$-AR blockers, silodosin $8 \mathrm{mg}$ therapy can be an alternative for proceeding medical therapy. In LUTS/BPH patients with a poor response to at least 4 weeks of their own $\alpha$-blocker, switching to silodosin 8 mg improves LUTS/BPH and related QoL.

There are different studies in the literature about switching $\alpha$-AR blockers to another. Masciovecchio et al. assessed the clinical outcomes associated with switching to silodosin in patients who did not respond to tamsulosin therapy and after a 8-week treatment they found a significant improvement in IPSS total score, and QoL scale [21]. They also analyzed the specific subscores of the IPSS questionnaire and reported that a significant improvement was observed in storage symptoms, but not in voiding symptoms. On the other hand Tanaka et al. reported that switching to silodosin besides improving the other parameters exhibited a more strong effect on voiding symptoms than on storage symptoms, but they have found no significant improvement in the post-micturition symptoms [23]. Recently, a new study was published by Yoshida et al [24] whom declared silodosin as an effective first-line $\alpha$ AR blocker monotherapy, even in those who still have moderate lower urinary tract symptoms in their study. Silodosin, a highly selective $\alpha$-ARs blocker, is the most recently approved of the commercially available $\alpha$-blockers [10].

Overall, switching to a 3-months silodosin treatment determined a significant improvement in IPSS total score, and QoL scale was observed. All patients had been previously treated with a recommended treatment associated with LUTS, without showing response; therefore, an improvement in IPSS after switching to silodosin appears clinically relevant.

Noteworthy studies have shown that silodosin also improves the urodynamic parameters [25-27]. In this way silodosin improves voiding, and storage symptoms and Qmax in men with LUTS associated with BPH [15]. In our study, silodosin exhibited a strong effect on both voiding symptoms and on storage symptoms.

This present study has some limitations due to the number of patients which each study arm was relatively small, the short duration of observation, and the lack of a control.

\section{Conclusion}

In patients with BPH who did refuse surgical treatment and could not achieve adequate symptom relief with other $\alpha$-blockers in routine practice, silodosin was found superior in terms of LUTS recovery. Decrease in IPSS, PVR and increase in Qmax and QoL scale were higher in the group receiving silodosin treatment compared to the group using other alpha blockers. Silodosin is also an effective option in patients who cannot undergo surgical treatment due to comorbidities.

Ethics Committee Approval: The study was approved by the Ethics Committee of University of Health Sciences, Derince Training and Research Hospital, Kocaeli, Turkey (Approval date, and registration number: 11.06.2020/62).

Informed Consent: An informed consent was obtained from all the patients.

Publication: The results of the study were not published in full or in part in form of abstracts.

Peer-review: Externally peer-reviewed.

Authorship Contributions: Any contribution was not made by any individual not listed as an author. Concept - B.V., O.M.; Design - B.V., M.U., O.M.; Supervision - B.V., M.U., L.O.; Resources - O.K., M.U., L.O.; Materials - O.K., O.M., L.O.; Data Collection and/or Processing -O.K., M.U., L.O.; Analysis and/or Interpretation - B.V., O.M., O.K; Literature Search O.K., M.U., L.O.; Writing- B.V., O.M.; Critical Review - B.V., M.U., L.O.

Conflict of Interest: The authors declare that they have no conflict of interest.

Financial Disclosure: The authors declare that this study received no financial support.

\section{References}

[1] Xu D, Wu Y, Shen H, Qian S, Qi J. High serum concentration of estradiol may be a risk factor of prostate enlargement in aging male in China. Aging Male 2020;23:1-6. https://doi.org/10.1080/13685538.2018.1481027.

[2] Nicholson TM, Ricke WA. Androgens and estrogens in benign prostatic hyperplasia: Past, present and future. 
Differentiation 2011;82:184-99. https://doi.org/10.1016/j.diff.2011.04.006.

[3] Lepor H. Alpha blockade for the treatment of benign prostatic hyperplasia. Urol Clin North Am 1995;22:375-86. https://doi.org/10.1016/s0094-0143(21)00673-x.

[4] Kojima Y, Sasaki S, Shinoura H, Hayashi Y, Tsujimoto G, Kohri K. Quantification of alpha1-adrenoceptor subtypes by real-time RT-PCR and correlation with age and prostate volume in benign prostatic hyperplasia patients. Prostate 2006;66:761-7. https://doi.org/10.1002/pros.20399.

[5] Nasu K, Moriyama N, Kawabe K, Tsujimoto G, Murai M, Tanaka T, et al. Quantification and distribution of $\alpha 1$-adrenoceptor subtype mRNAs in human prostate: Comparison of benign hypertrophied tissue and nonhypertrophied tissue. Br J Pharmacol 1996;119:797-803. https://doi.org/10.1111/j.1476-5381.1996.tb15742.x.

[6] Walden PD, Gerardi C, Lepor H. Localization and expression of the $\alpha 1 \mathrm{~A}-1, \alpha 1 \mathrm{~B}$ and a1D-adrenoceptors in hyperplastic and non-hyperplastic human prostate. J Urol 1999;161:635-40.

https://doi.org/10.1016/S0022-5347(01)61986-4.

[7] Faure C, Pimoule C, Vallancien G, Langer SZ, Graham D. Identification of $\alpha 1$-adrenoceptor subtypes present in the human prostate. Life Sci 1994;54:1595-605. https://doi.org/10.1016/0024-3205(94)90031-0.

[8] Forray C, Bard JA, Wetzel JM, Chiu G, Shapiro E, Tang $\mathrm{R}$, et al. The $\alpha 1$-adrenergic receptor that mediates smooth muscle contraction in human prostate has the pharmacological properties of the cloned human $\alpha 1 \mathrm{c}$ subtype. Mol Pharmacol 1994;45:703-8.

https://pubmed.ncbi.nlm.nih.gov/8183249/.

[9] Lowe F. Alpha-1-adrenoceptor blockade in the treatment of benign prostatic hyperplasia. Prostate Cancer Prostatic Dis 1999;2:110-9. https://doi.org/10.1038/sj.pcan.4500302.

[10] Matsukawa Y, Gotoh M, Komatsu T, Funahashi Y, Sassa N, Hattori R. Efficacy of Silodosin for Relieving Benign Prostatic Obstruction: Prospective Pressure Flow Study. J Urol 2009;182:2831-5. https://doi.org/10.1016/j.juro.2009.08.030.

[11] Tatemichi S, Kobayashi K, Maezawa A, Kobayashi M, Yamazaki Y, Shibata N. $\alpha 1$-adrenoceptor subtype selectivity and organ specificity of silodosin (KMD-3213). Yakugaku Zasshi 2006;126:209-16. https://doi.org/10.1248/yakushi.126.209.

[12] Shibata K, Foglar R, Horie K, Obika K, Sakamoto A, Ogawa S, et al. KMD-3213, a novel, potent, $\alpha(1 \mathrm{a})$ adrenoceptor-selective antagonist: Characterization using recombinant human $\alpha 1$-adrenoceptors and native tissues. Mol Pharmacol 1995;48:250-8. https://pubmed.ncbi.nlm.nih.gov/7651358/.

[13] Martin DJ, Angel I, Arbilla S. Functional uroselectivity. Eur Urol 1998;33:12-8. https://doi.org/10.1159/000052229.

[14] Moriyama N, Akiyama K, Murata S, Taniguchi J, Ishida N, Yamazaki S, et al. KMD-3213, a novel $\alpha(1 \mathrm{~A})$-adrenoceptor antagonist, potently inhibits the functional $\alpha 1$-adrenoceptor in human prostate. Eur J Pharmacol 1997;331:39-42. https://doi.org/10.1016/S0014-2999(97)01009-1.

[15] Keating GM. Silodosin: A review of its use in the treatment of the signs and symptoms of benign prostatic hyperplasia. Drugs 2015;75:207-17. https://doi.org/10.1007/s40265-014-0344-z.

[16] Samli MM, Dincel C. Terazosin and doxazosin in the treatment of BPH: Results of a randomized study with crossover in non-responders. Urol Int 2004;73:125-9. https://doi.org/10.1159/000079692.

[17] Madersbacher S, Alivizatos G, Nordling J, Sanz CR, Emberton M, De La Rosette JJMCH. EAU 2004 guidelines on assessment, therapy and follow-up of men with lower urinary tract symptoms suggestive of benign prostatic obstruction (BPH guidelines). Eur Urol 2004;46:547-54. https://doi.org/10.1016/j.eururo.2004.07.016.

[18] McVary KT, Roehrborn CG, Avins AL, Barry MJ, Bruskewitz RC, Donnell RF, et al. Update on AUA guideline on the management of benign prostatic hyperplasia. J Urol 2011;185:1793-803. https://doi.org/10.1016/j.juro.2011.01.074.

[19] Araki T, Monden K, Araki M. Comparison of 7 aladrenoceptor antagonists in patients with lower urinary tract symptoms associated with benign prostatic hyperplasia: A short-term crossover study. Acta Med Okayama 2013;67:245-51. https://doi.org/10.18926/AMO/51069.

[20] Miyakita H, Yokoyama E, Onodera Y, Utsunomiya T, Tokunaga M, Tojo T, et al. Short-term effects of crossover treatment with silodosin and tamsulosin hydrochloride for lower urinary tract symptoms associated with benign prostatic hyperplasia. Int J Urol 2010;17:869-75. https://doi.org/10.1111/j.1442-2042.2010.02614.x.

[21] Masciovecchio S, Di Pasquale AB, Ranieri G, Romano G, Di Clemente L. Role of silodosin in patients with LUTS/BPE non responding to medical treatment with tamsulosin: a prospective, open-label, pilot study. Eur Rev Med Pharmacol Sci 2017;21:4941-5. https://pubmed.ncbi.nlm.nih.gov/29164564/.

[22] Fonseca J, Martins da Silva C. The Diagnosis and Treatment of Lower Urinary Tract Symptoms due to Benign Prostatic Hyperplasia with $\alpha$-Blockers: Focus on Silodosin. Clin Drug Investig 2015;35:7-18. https://doi.org/10.1007/s40261-014-0257-3. 
[23] Tanaka M, Niimi A, Tomita K, Homma Y. Conversion to silodosin in men on conventional al-blockers for symptomatic benign prostatic hyperplasia. LUTS Low Urin Tract Symptoms 2010;2:11-5. https://doi.org/10.1111/j.1757-5672.2010.00055.x.

[24] Yoshida M, Origasa H, Seki N. Comparison of Silodosin versus Tadalafil in Patients with Lower Urinary Tract Symptoms Associated with Benign Prostatic Hyperplasia. LUTS Low Urin Tract Symptoms 2017;9:176-86. https://doi.org/10.1111/luts.12177.

[25] Yamanishi T, Mizuno T, Tatsumiya K, Watanabe M, Kamai T, Yoshida KI. Urodynamic effects of silodosin, a new ala-adrenoceptor selective antagonist, for the treatment of benign prostatic hyperplasia. Neurourol Urodyn 2010;29:558-62.

https://doi.org/10.1002/nau.20802.
[26] Fusco F, Palmieri A, Ficarra V, Giannarini G, Novara G, Longo N, et al. $\alpha 1$-Blockers Improve Benign Prostatic Obstruction in Men with Lower Urinary Tract Symptoms: A Systematic Review and Meta-analysis of Urodynamic Studies. Eur Urol 2016;69:1091-101. https://doi.org/10.1016/j.eururo.2015.12.034.

[27] Fusco F, Creta M, Imperatore V, Longo N, Imbimbo C, Lepor $\mathrm{H}$, et al. Benign Prostatic Obstruction Relief in Patients with Lower Urinary Tract Symptoms Suggestive of Benign Prostatic Enlargement Undergoing Endoscopic Surgical Procedures or Therapy with Alpha-Blockers: A Review of Urodynamic Studies. Adv Ther 2017;34:773-83. https://doi.org/10.1007/s12325-017-0504-0. 